\title{
CPUE trends of Hilsa kelee and Thryssa vitrirostris exploited by the artisanal finfish fisheries in Mozambique derived from an on-shore sampling of catches by trip
}

\author{
Massimiliano Cardinale ${ }^{1}$, Osvaldo Chacate ${ }^{2}$, Michele Casini ${ }^{1}$, Isabel Chaúca ${ }^{2}$, \\ Jon Helge Vølstad ${ }^{3}$ \\ ${ }^{1}$ Swedish University of Agricultural Sciences, Department of Aquatic Resources, 45330, Lysekil, Sweden. \\ E-mail: massimiliano.cardinale@slu.se \\ ${ }^{2}$ National Fisheries Research Institute, Mao Tse Tung Avenue 389, Maputo, Mozambique. \\ ${ }^{3}$ Institute of Marine Research, P.O. Box 1870 Nordnes, N-5817 Bergen, Norway.
}

\begin{abstract}
Summary: Artisanal fisheries are often overlooked by fisheries management agencies despite their great importance for food security and livelihoods. The assessment and management of those fisheries is often rare, especially in developing countries. In Mozambique, a probability-based survey for the monitoring of the small-scale fisheries has been conducted in several coastal provinces since the late 1990's. Here we used the Mozambican on-shore data collection programme to illustrate both the difficulties and possibilities of estimating trends in catch per unit of effort (CPUE in $\mathrm{kg} \mathrm{day}^{-1}$ ) for stocks when data is limited in both quantity and quality, as is often the case for artisanal fisheries. Data on catch and effort collected between 1998 and 2009 from four regions along the Mozambican coast and two different gears were used to assess the status of two species (Hilsa kelee and Thryssa vitrirostris) exploited by the artisanal fisheries. The results showed that standardized CPUE have declined for some of the regions and gears analysed, whereas for others the trend has been stable or has even increased during the last 12 years. However, when CPUE is scaled for the increase in net length, most of the times series show a declining trend.
\end{abstract}

Keywords: artisanal fisheries; Mozambique; CPUE.

Tendencias de la CPUE de Hilsa kelee y Thryssa vitrirostris explotadas por la pesquería artesanal en Mozambique a partir del muestreo de las capturas en puerto

Resumen: La pesca artesanal casi nunca se tiene en cuenta por las agencias de gestión de la pesca a pesar de su gran importancia para la seguridad alimentaria y medios de vida. La evaluación y la gestión de estas pesquerías no es muy frecuente, especialmente en los países en desarrollo. Desde finales de 1990 en varias provincias de la costa de Mozambique se llevó a cabo un seguimiento de las pesquerías artesanales basado en un muestreo probabilístico. Aquí hemos utilizado el programa de obtención de datos en el puerto de Mozambique para ilustrar las dificultades y posibilidades de la estimación de las tendencias de la captura por unidad de esfuerzo (CPUE en $\mathrm{kg} \mathrm{día}^{-1}$ ) para los stocks cuando los datos son limitados en cantidad y en calidad, como sucede a menudo en el caso de la pesca artesanal. Se utilizaron datos de captura y esfuerzo recogidos entre 1998 y 2009, en cuatro regiones a lo largo de la costa de Mozambique y con dos artes de pesca distintos, para evaluar el estado de las dos especies (Hilsa kelee y Thryssa vitrirostris) explotadas por las pesquerías artesanales. Los resultados mostraron que la CPUE estandarizada se ha reducido para algunas de las regiones y artes analizados, mientras que para otros la tendencia se ha mantenido estable o incluso ha aumentado durante los últimos 12 años. Sin embargo, cuando se escala la CPUE para el aumento de la longitud de la red, la mayor parte de la serie de tiempos muestra una tendencia a la baja.

Palabras clave: pesquería artesanal, Mozambique, CPUE.

Citation/Como citar este artículo: Cardinale M., Chacate O., Casini M., Chaúca I., Vølstad J.H. 2014. CPUE trends of Hilsa kelee and Thryssa vitrirostris exploited by the artisanal finfish fisheries in Mozambique derived from an on-shore sampling of catches by trip. Sci. Mar. 78(1): 55-64. doi: http://dx.doi.org/10.3989/scimar.03826.06C

Editor: D. Vaqué.

Received: February 1, 2013. Accepted: December 12, 2013. Published: March 6, 2014.

Copyright: (c) 2014 CSIC. This is an open-access article distributed under the Creative Commons Attribution-Non Commercial Lisence (by-nc) Spain 3.0. 


\section{INTRODUCTION}

Coastal areas worldwide are characterized by an increasing population density, which strains inshore marine resources especially in countries such as tropical ones, where a large part of the coastal population may depend on marine fish and shellfish for subsistence (Salas et al. 2007, Allison and Ellis 2001). Moreover, as for many of the exploited fish stocks in the world oceans (Hutchings and Reynolds 2004, but see also Cardinale 2011 and Cardinale et al. 2013), coastal resources are also increasingly depleted (Davies et al. 2009). Hence, the assessment of the status of exploited coastal resources to be used for a sustainable management of marine resources and ecosystems is urgent.

In general, coastal areas of developing countries are mostly exploited by artisanal fisheries (Salas et al. 2007), but quantitative knowledge of the status of the exploited stocks is often incomplete (e.g. Salas et al. 2007). Artisanal fisheries in developing countries have been notoriuosly difficult to manage because the status and trends (in biomass or abundance) of marine resources have been difficult to assess. This is due to the complexity of artisanal fisheries, which are characterized by a great diversity of species and gears, as well as numerous landing sites that are difficult to access, making data collection difficult to conduct. Moreover, developing countries often have poorly developed management infrastructures. Thus, in developing countries little is generally known about the overall nature of the artisanal fisheries and the status of the resources they exploit.

Because of the difficulty of data collection in developing countries, catch and effort data form an important, and often the sole, source of data for fish stock assessment. Population parameters important for management are often estimated by fitting production models to standardized series of catch-per-unit-effort (CPUE) (Xiao 1998) or the stock status is simply assessed by analysing trends in standardized CPUE (e.g. Cardinale et al. 2009). Such basic information is notoriously hard to obtain for artisanal fisheries because of the spatial and temporal dynamics in effort, numerous landing sites and limited access (Pauly and Mines 1982, Munro 1983).

In Mozambique, artisanal fisheries targetting the coastal marine resources are highly important for a large sector of the population. At present there are more than 100000 fishers in Mozambique, distributed in 1217 fishing centres and villages, of which $70 \%$ are located along the marine coastline (IDPPE 2009). In a census performed in 2002, it was estimated that approximately 70000 of those fishers were involved in the artisanal fisheries in Mozambique (IDPPE 2004). The number of artisanal fisherman involved in marine fisheries approximately doubled between 2002 and 2007, while the number of boats increased by about $35 \%$ (IDPPE 2009). In Mozambique, more than 130000 people are directly dependent on coastal fisheries and the amount is steadily increasing (IDPPE 2009).

In Mozambique, a probability-based survey for the monitoring of the artisanal fisheries has been conducted in several coastal provinces since the 1997. The sampling frame in Mozambique is a matrix of landing sites and days. The fishery concerned operates from beaches, or in near coastal waters (generally within 5 $\mathrm{km}$ ), and it is dominated by beach seines, hand lines and gillnets deployed by a mixed fleet of vessels less than $10 \mathrm{~m}$ in size. Vessels usually conduct daily fishing trips using one type of gear, but in some cases multiple gears are employed simultaneously. The vast majority of fishing trips can be accessed for sampling at a finite list of landings sites along the coast.

Despite more than a decade of regular data collection, no assessment has been conducted of the target species exploited by the artisanal fisheries along the whole Mozambiquan coastline. The CPUE trends published in Mozambican national official reports are usually given by gear and by fish family, and not by species or by area (but see Mualeque and Santos 2011), and are not standardized by effort (e.g. net length) and other changes in fleet features and behaviour (IIP 2007). Moreover, fisheries-independent surveys of the coastal fisheries resources in Mozambique are not conducted regularly. Therefore, little information is available to assess the current status of the exploited resources against a historical baseline (but see Loureiro 2001).

In general, management of resources exploited by small-scale fisheries, which are based on a quantitative estimation of the impact of the fleet on the stock, are rare. For example, in the Mediterranean there is one single case for which the impact (in terms of partial fishing mortality exerted by the fleet) of the small-scale fisheries on common sole (Solea solea) is assessed (i.e. sole in the Adriatic Sea; STECF 2013), although management of this stock does not take the assessment results into consideration but is based solely on technical measures. In Vietnam, a TAC (Total Allowable Catches) management system is in place, although the TAC setting is not based on quantitative stock assessment and the real impact of the fleet on the stock is unkown (Pomeroy et al. 2009).

The main objectives of this paper were to collate and analyse a database on commercial artisanal fisheries collected between 1998 and 2009 along the Mozambican coast. An assessment of the trend in standardized CPUE was conducted for two of the most important commercial species landed by the small-scale fisheries, Hilsa kelee and Thryssa vitrirostris (Loureiro 2001, Mualeque and Santos 2011). Trend in CPUE from gillnets and beach seines from four provinces (Maputo, Inhambane, Nampula and Zambezia) were estimated. This is the first attempt to produce standardized time series of CPUE for the small-scale fisheries along the Mozambican coast

Here we used the Mozambican data collection programme to illustrate both the difficulties and possibilities of making assessment of trends in stocks when data are limited in both quantity and quality, as is often the case for artisanal fisheries in developing countries. We also provide a novel trend analysis of the target species of the Mozambican artisanal fisheries, which is urgently needed for the management of Mozambican coastal marine resources. 


\section{MATERIALS AND METHODS}

\section{Data collection}

A probability-based on-shore catch sampling programme has been used to monitor the small-scale fisheries in Mozambique since the late 1990s (ICES 2010). The sampling frame is a matrix of landing sites crossed with days of the year, the site-days being the primary sampling units (PSUs) (ICES 2013). The PSUs are stratified on the basis of geography, and in some cases their size on the basis of number of registered fishing gears. Sampling of landing sites is scheduled on random days during each calendar week from each stratum to ensure good temporal coverage in each stratum. Sampling sizes of site-days per stratum are allocated in a manner that is approximately proportional to expected effort, using comprehensive information from the 1996 atlas of the artisanal fishery and the 2002 national census conducted by the Institute for the Development of Small-Scale Fisheries (IDPPE 2004). The sumpling design is flexible and provides reliable catch and effort data for the different gears and species caught along the entire Mozambican coastline (ICES 2010). Data on catch size and catch composition are collected from all fishing units (single fishing vessel; secondary sampling units) in a PSU when feasible, or from a representative sample of units in each selected PSU by local agents contracted by the National Institute of Fisheries Research (IIP) and the Institute of for development of Small-Scale Fisheries (IDPPE). The dominant gear is beach seines operated from an artisa-

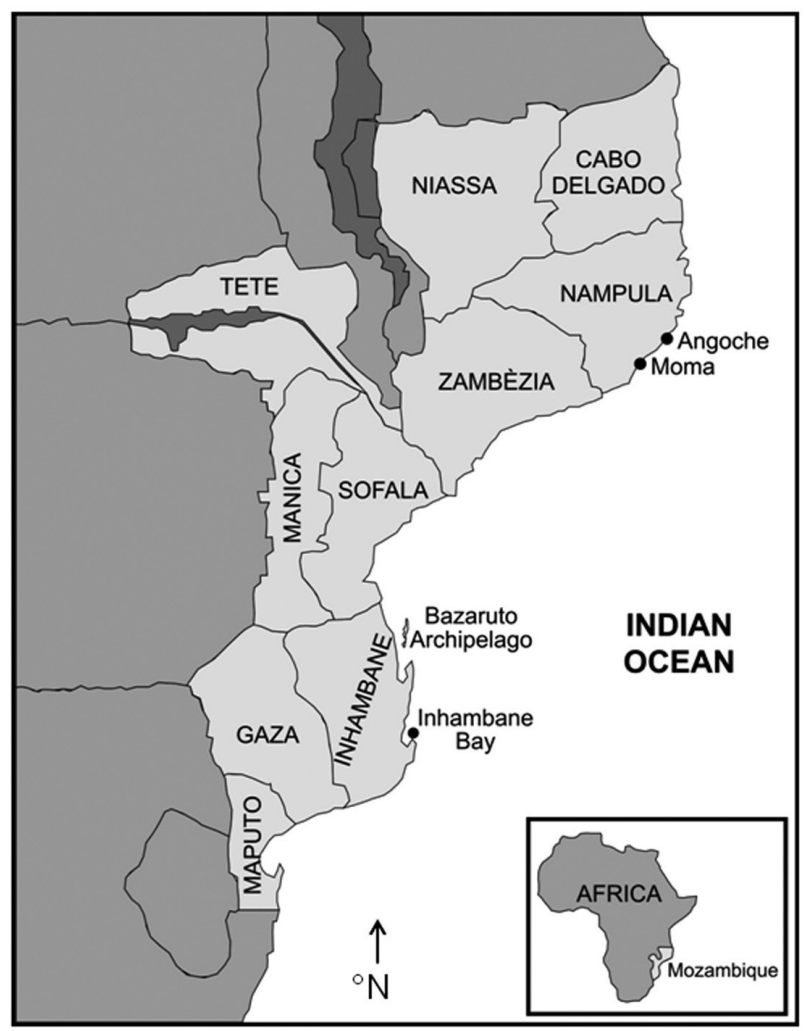

Fig. 1. - Map of the study area, with the different provinces and principal fishing centres where the sampling was carried out. The full list of the fishing centres used in the analysis is reported in Table 2.
Table 1. - Landings in tonnes from the different gears used in the artisanal fisheries from 2004 to 2008 .

\begin{tabular}{lrrrrr}
\hline Year & 2004 & 2005 & 2006 & 2007 & 2008 \\
\hline Beach seine & 43384 & 38927 & 42314 & 35896 & 32984 \\
Hook and line & 5884 & 5527 & 4160 & 6537 & 6953 \\
Gillnet & 8380 & 13075 & 9865 & 13966 & 16165 \\
Other gears & 1842 & 1902 & 3090 & 3031 & 3328 \\
\hline
\end{tabular}

nal vessel, and catch data are generally obtained from completed trips when the fishermen land their catch. To assure high quality of field data collections with respect to representativeness of sampling and species identifications, a biologist from IIP or IDPPE accompanied by a field data collector agent made a visit once per month during the implementation of the sampling in a stratum and once every two months thereafter. A meeting with all field data collector agents in a province is held once per year to ensure consistent data collection, and a national meeting between IIP supervisors and provincial coordinators of field collections is held once every two years to ensure consistency among provinces. Data on catch per trip used in the analysis here were collected from 1998 to 2009. The coastal areas of Mozambique are part of seven different provinces (Fig. 1) and can be divided into three macro-areas, where the artisanal fisheries operate:

The northern coast (about $770 \mathrm{~km}$ ), with a rocky and coral-bearing sea bed and a narrow continental shelf, with sheltered islands and bays, streaching from the boarder with Tanzania in Cabo Delgado Province to northern Nampula province.

The central coast (about $980 \mathrm{~km}$ ) facing the Sofala bank and including most of the Zambezia province. This area is mainly influenced by the numerous rivers and channels and mangrove forests and extends from the more southerly districts of Nampula province to the north of Inhambane province.

The southern coast, which is about $950 \mathrm{~km}$ long and is characterized by coral and rocks in some areas and sand in others. It stretches from the southern part of Inhambane province to the border with South Africa, in Maputo province.

The marine artisanal fishery is conducted by a fleet of vessels less than $10 \mathrm{~m}$ in length and it usually operates in coastal waters within three miles off land. Daily fishing trips are the norm for most vessels, and fishing is typically conducted from the beach or sand banks using one type of gear, while multiple gears are employed simultaneously only by a limited number of vessels (i.e. less than $5 \%$ in general). Beach seines account for most of the catches, while the remaining catches are taken mainly by gill nets, hand lines and long lines (Table 1). The fleet consists of 39400 boats, of which $77 \%$ are canoes. Motorized vessels account for only $1.5 \%$ of the total fleet and have not increased in number since 2002 (IDPPE 2009).

Sampling of landings in the coastal artisanal fisheries is conducted from representative landing sites selected within districts in the different provinces (Table 2 and Fig. 1). The geographical origin of the catch is assigned according to the information collected during sampling. The geographical origin of the catches was inferred by interviewing the fishermen at the landing 
$\mathbf{5 8} \cdot$ M. Cardinale et al.

Table 2. - Number of site-day observations collected for each year and landing site in the provinces of Maputo, Inhambane, Nampula and Zambezia and used in the analysis.

\begin{tabular}{|c|c|c|c|c|c|c|c|}
\hline $\begin{array}{l}\text { Province } \\
\text { Year }\end{array}$ & $\begin{array}{c}\text { Maputo } \\
\text { Baia de Maputo }\end{array}$ & Ilha de Inhaca & Macaneta & Maputo & Marracuene & Matola & Matutuine \\
\hline 1998 & 25 & & & & & & \\
\hline 1999 & 333 & & & & & & \\
\hline 2000 & 119 & & & & & & \\
\hline 2001 & 566 & & & & & & \\
\hline 2002 & 481 & & & & & & \\
\hline 2003 & 331 & & & & & & \\
\hline 2004 & 385 & & & & & & \\
\hline 2005 & 425 & & & & & & \\
\hline 2006 & 28 & & & & & & \\
\hline 2007 & & 13 & 883 & 477 & & 590 & 800 \\
\hline 2008 & & 65 & 809 & 559 & & 411 & 766 \\
\hline 2009 & & 81 & 34 & 1151 & 671 & 487 & 433 \\
\hline
\end{tabular}

\begin{tabular}{|c|c|c|c|c|c|c|c|c|c|c|c|}
\hline $\begin{array}{l}\text { Province } \\
\text { Year }\end{array}$ & $\begin{array}{l}\text { Inhambane } \\
\text { Baia de } \\
\text { Inhambane }\end{array}$ & Bazaruto & Govuro & $\begin{array}{c}\text { Ibane } \\
\text { Município }\end{array}$ & Inhambane & Inhassoro & Jangamo & Maxixe & Morrumbene & Tofo & Vilanculos \\
\hline 1997 & 509 & & & & & & & & & & \\
\hline 1998 & 265 & & & & & & & & & & 4 \\
\hline 1999 & 693 & & & & & 777 & & & & & 551 \\
\hline 2000 & 961 & & & & & 1814 & & & & & 854 \\
\hline 2001 & 920 & 5 & & & 3 & 1228 & & & & & 666 \\
\hline 2002 & 915 & & & & 5 & 1035 & & & & & 608 \\
\hline 2003 & 587 & 1 & & & 11 & 732 & & & & & 335 \\
\hline 2004 & 262 & & & & 5 & 367 & & & & & 150 \\
\hline 2005 & 762 & & & & 6 & 569 & & & & & 280 \\
\hline 2006 & 622 & 1153 & 79 & & 11 & 509 & & & & & 421 \\
\hline 2007 & 498 & 706 & 1054 & & 14 & 377 & & & & & 649 \\
\hline 2008 & 759 & 445 & 580 & & 10 & 406 & & & & & 758 \\
\hline 2009 & & 725 & 830 & 164 & & 456 & 71 & 272 & 127 & 15 & 1087 \\
\hline
\end{tabular}

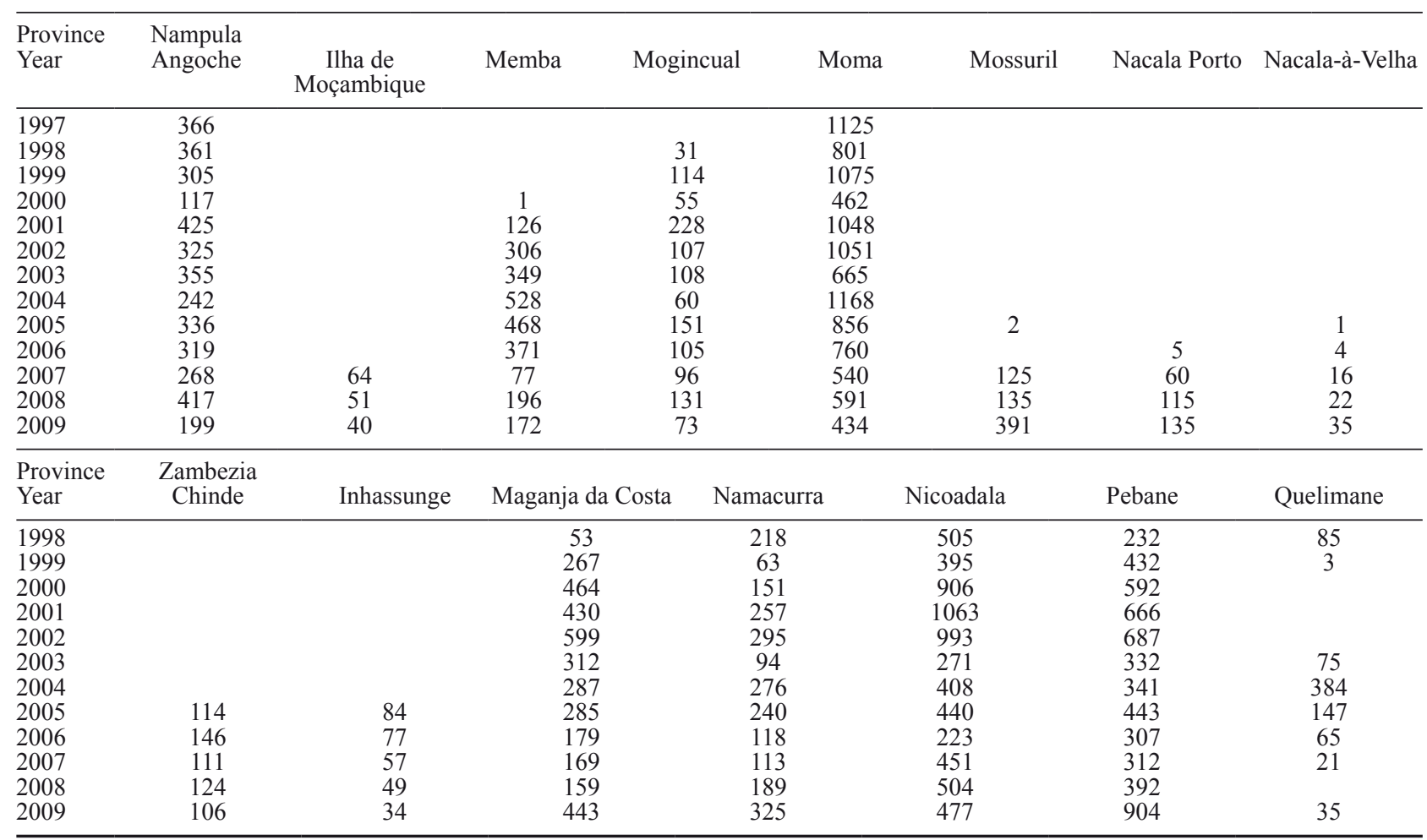

site during sampling. Information was also collected on gear type and gear characteristics (length of the net) for each species.

\section{Standardization of the CPUE}

In this paper we have treated each trip as the primary sampling unit, and have assumed that trips with- in each province were sampled with equal probability within a year. Since the sampling of landing sites is approximately proportional to the activity level (e.g. more trips were sampled from large landing sites than from small ones), this assumption is likely to be reasonably supported. The analysis was conducted for beach seines and gillnets. Catches from those gears constituted more than $82 \%$ of the total catch of the 
fleet between 2004 and 2008 (Table 1, IIP 2007). CPUEs were estimated as the catch in weight per day of fishing $\left(\mathrm{kg} \mathrm{day}^{-1}\right)$ for two of the most important species caught by the artisanal fisheries, Hilsa kelee (HKE) and Thryssa vitrirostris (TVI). Beach seines and gillnets were chosen as they were considered to target the selected species.

To account for the unbalanced design in the sampling between year and month, generalized additive models (GAMs; Hastie and Tibshirani 1990) were used. GAMs offer the main advantage that they can be used to model non-linearity, which often relates the biological data to the predicting factors. We used a quasi-Poisson distribution (Minami et al. 2007) to model CPUE with variance proportional to the mean and a log-link function in order to constrain the estimates of CPUE to be positive. The quasi-likelihood approach in the quasi-Poisson distribution assumes that the scale parameter $\Phi$ of the distribution is unknown so that it could account for more over-dispersion than the classical Poisson distribution (Wood 2006). Therefore, it has greater flexibility in fitting the data distributions, especially for zero-inflated data. A model for each species, gear and province was fitted:

$$
\text { CPUE }\left(\mathrm{kg} \mathrm{day}^{-1}\right) \sim \mathrm{s}(\text { year})+\mathrm{s}(\text { month })
$$

Year was modelled using an isotropic smooth (thin plate regression spline) function (Wood 2004). A cyclic cubic regression spline was chosen to smooth the month predictor because it forces the smoothing to have the same value and first few derivatives at its initial and final points. In order to simplify the interpretation of the results, the maximum number of knots was limited for the smooth term of month $(\mathrm{k} \leq 4)$.

First, all the predictors were included in the model (full model) and a backward stepwise regression was applied. Smoothing parameter estimation and model selection were based on generalized cross validation (GCV; Wood 2001, 2004) information criteria. The GCV of a model is a proxy for the model's out-ofsample predictive mean squared error. Therefore, a model with lower GCV has more explanatory power than, and hence is preferred to, a model with higher GCV. Final models were selected on the basis of GCV criteria and the significance of the predictors fulfilled at the same time. The predicted year effect after scaling out the effects of the other predictor was estimated on the scale of the response from the final models. Residuals were analysed to inspect for homogeneity of variance and violation from normality assumptions or other anomalies in the data or in the model fit using graphical methods (Cleveland 1993). Technological creep was not accounted for in this analysis (see Cardinale et al. 2009 for a useful discussion and modelling of technological creep). However, changes in fishing technology over the study period are considered negligible (ICES 2010). The use of monofilament in the fishing gears had already increased massively before the start of our time series (the early 1980s; ICES 2010) and therefore it is unlikely to have affected our analyses.

\section{Effect of changes in effort on CPUE}

Data on net length (both for gillnets and beach seines) were available, but their collection did not cover all years and provinces. Using available net length information in the GAMs would reduce the number of available observations (less than $20 \%$ of the current data set contains net length information and moreover the data are patchy and irregularly scattered between landings site, provinces and years). Thus, first the overa 1 year average effort (in terms of the length of the gillnets and beach seines) per vessel and gear type (i.e. gillnet and beach seines) for the four analysed provinces was estimated using available data. Successively, the CPUE $\left[\mathrm{kg} \mathrm{day}^{-1}\right.$ (net length) $\left.{ }^{-1}\right]$ estimated by the final GAM models for each province and gear was divided by the overall year average effort of that province and gear. The analyses were performed using the mgcv library of R (Wood 2001, www.r-project.org).

\section{RESULTS}

The yearly average CPUE for all species caught declined from 1999 to 2009 (Fig. 2). Also, yearly average CPUE for HKE and TVI declined during the same period. The average net length employed per vessel for gillnet generally increased for the provinces of Maputo, Inhambane, Nampula and Zambezia over the time series (1999-2009) (Fig. 3A). For beach seines, a similar trend was present for Zambezia, while there was no increase in the length of the net for the other provinces (Fig. 3B).

For investigated species, provinces and gear, the full model was selected as the final model since it always resulted in the lowest GCV with all variables significant at $p<0.0001$, except for TVI caught by beach seines in Maputo province (Table 3). Deviance explained by the final models ranged between $1.6 \%$ and $57.5 \%$ (Table 3) with small uncertainties around the means. For TVI caught with gillnet in the Inhambane province, the model gives unrealistic results in terms of

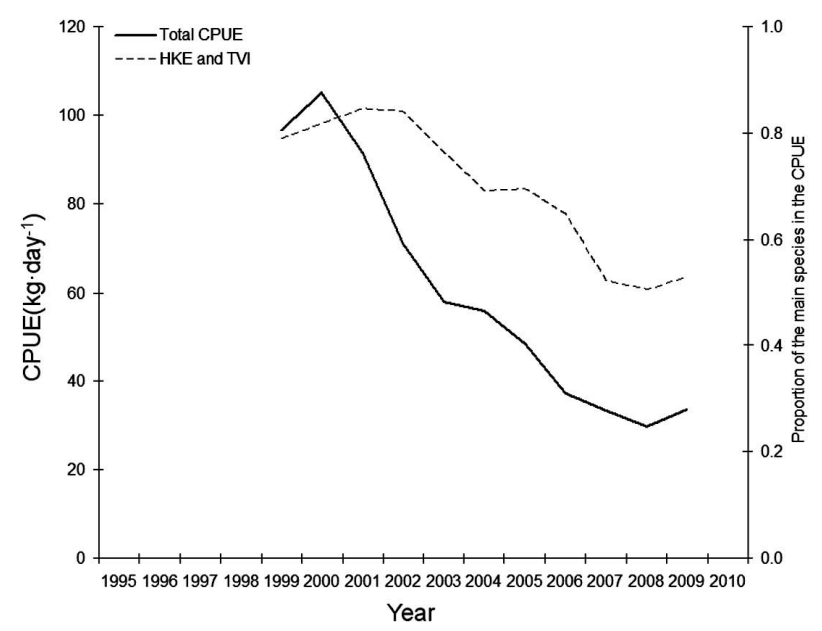

Fig. 2. - Trend in the total CPUE $\left(\mathrm{kg} \mathrm{day}^{-1}\right)$ and in the proportion of the Hilsa kelee and Tryssa vitrirostris in the total CPUE for the four provinces analysed. 


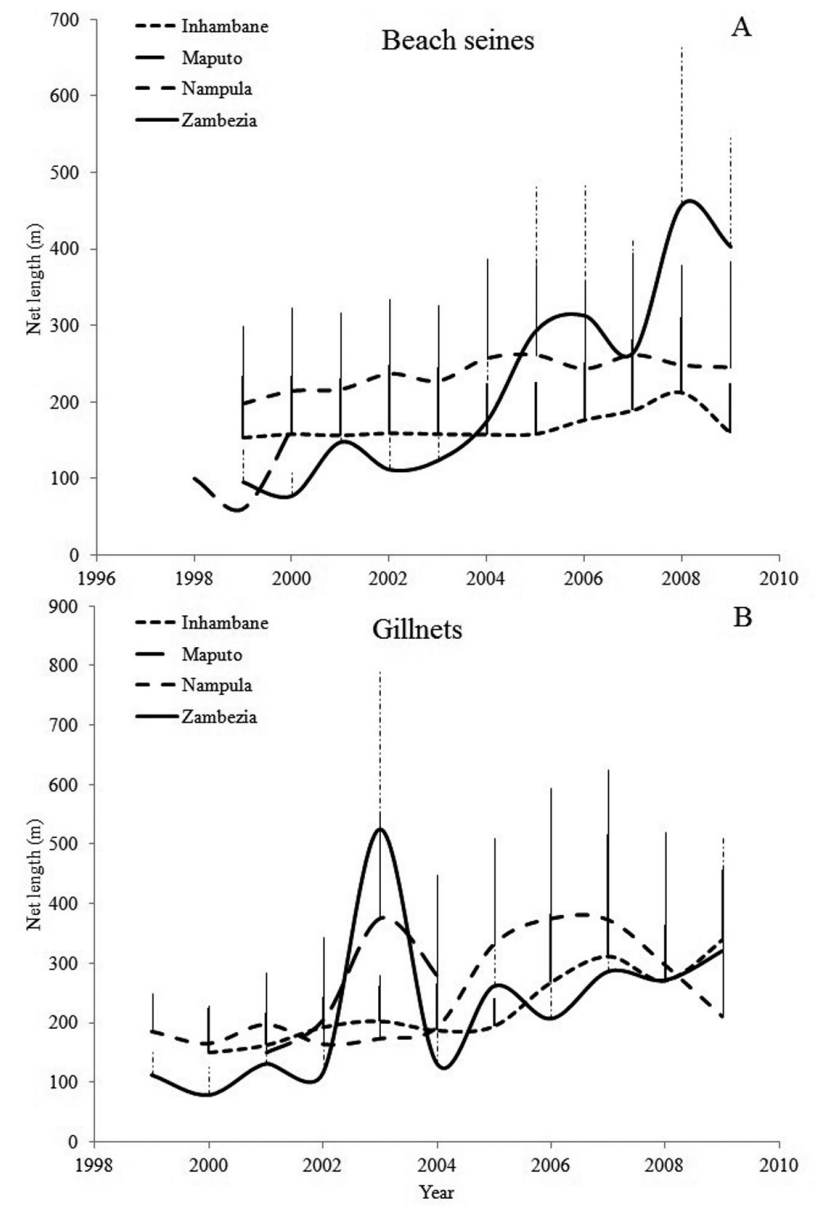

Fig. 3. - Trend in effort expressed as the yearly average net length for gillnet (A) and beach seines (B) with the estimated standard error for each province.

model fitting and it was excluded. Residuals were generally slightly right-skewed or normally distributed for the final models (data not shown). This implies that the final models are less able to predict very large catches.

The peak in CPUE for HKE caught by gillnet was observed in April-May or July-August, depending on the province (Fig. 4A). For HKE caught by beach seines, a peak between December and January was estimated in the Maputo and Zambezia province, while for Inhambane and Nampula the highest CPUE were between May and June (Fig. 4A).

For TVI caught by gillnet, a peak between November and December was shown in Maputo and Zambezia province, while for Nampula the highest CPUE was in July (Fig. 4B). CPUE of TVI caught by beach seines showed a peak in December-January for Inhambane and Zambezia province, and in May for Nampula (Fig. 4B).

The year effect of the models showed that the CPUE for some of the gear and provinces analysed hase declined, whereas for others there has been a stable trend or an increase compared with the beginning of the time series (Figs 5-6). For example, HKE from gillnet has declined in Maputo, Namupla and Zambezia but has increased in Inhambane, although the latter time series is much shorter (Fig. 5). The decline is more pronounced when the effect of the increased net length is accounted for. In the beach seine fisheries, a similar trend was evident for the analysed provinces (Fig. 5).

For TVI, CPUE from gillnets was stable in all provinces when net length was not considered, but showed a decline in Nampula and Zambezia when net length was taken into account in the analysis (Fig. 6). A declining trend was also shown for CPUE of TVI from beach seines in Nampula and, after net length standardization, also in Zambezia, while no clear trend was observed in Maputo and Inhambane (Fig. 6).

\section{DISCUSSION}

Artisanal fisheries that target stocks within the coastal ecosystems have been largely ignored by fisheries management agencies, despite their great importance for food security and livelihoods (Vincent et al. 2007). It has been shown that local artisanal fisheries with a relatively low level of effort and technological development can significantly impact the coastal environment and the coral reef ecosystem, and therefore the monitoring of their impact is important (Hardt 2009). From a socio-economic and food security perspective, artisanal fisheries are critically important worldwide, as it has been estimated that around 50 million artisanal fishermen are active in developing countries and more than 400 million people rely on artisanal fisheries for

Table 3. - Summary of the results of the GAM models for each species, gear and province analysed. Deviance is the total deviance (in \%) explained by the model, Years is the range of years used in the analysis, $\mathrm{n}$ is the number of observations used in the model. The model code refers to the results reported in Figures 4, 5 and 6. BS, beach seine; GN, gillnet; ***the model gives unrealistic results and was excluded

\begin{tabular}{|c|c|c|c|c|c|c|c|c|}
\hline Species & Species code & Gear & Province & Model code & Predictors & Deviance $(\%)$ & Years & $\mathrm{n}$ \\
\hline \multirow[t]{8}{*}{ Hilsa kelee } & \multirow[t]{8}{*}{ HKE } & GN & Maputo & MAP_GN & full model & 30.4 & 1998-2009 & 8200 \\
\hline & & GN & Inhambane & INH_GN & full model & 38.5 & 1999-2009 & 1185 \\
\hline & & GN & Nampula & NAM_GN & full model & 9.7 & 1999-2009 & 5238 \\
\hline & & GN & Zambezia & ZAM_GN & full model & 7.7 & 1999-2009 & 1984 \\
\hline & & BS & Maputo & MAP_BS & full model & 34.3 & 1998-2009 & 1175 \\
\hline & & BS & Inhambane & INH_BS & full model & 30.2 & 1999-2009 & 8144 \\
\hline & & BS & Nampula & NAM_BS & full model & 6.5 & $1997-2009$ & 17349 \\
\hline & & BS & Zambezia & ZAM_BS & full model & 2.4 & 1998-2009 & 12175 \\
\hline \multirow{8}{*}{ Thryssa vitrirostris } & \multirow{8}{*}{ TVI } & GN & Maputo & MAP_GN & full model & 57.5 & $1999-2009$ & 6107 \\
\hline & & GN & Inhambane & INH_GN & full model & $* * *$ & $1999-2009$ & 559 \\
\hline & & GN & Nampula & NAM_GN & full model & 13.8 & $1999-2009$ & 4951 \\
\hline & & $\mathrm{GN}$ & Zambezia & ZAM_GN & full model & 8.1 & $1999-2009$ & 1535 \\
\hline & & $\mathrm{BS}$ & Maputo & MAP_BS & -MONTH & 19.1 & 1999-2009 & 1715 \\
\hline & & BS & Inhambane & INH_BS & full model & 53.1 & $1999-2008$ & 8488 \\
\hline & & BS & Nampula & NAM_BS & full model & 20.5 & $1997-2009$ & 19577 \\
\hline & & $\mathrm{BS}$ & Zambezia & ZAM_BS & full model & 1.6 & $1998-2009$ & 17848 \\
\hline
\end{tabular}



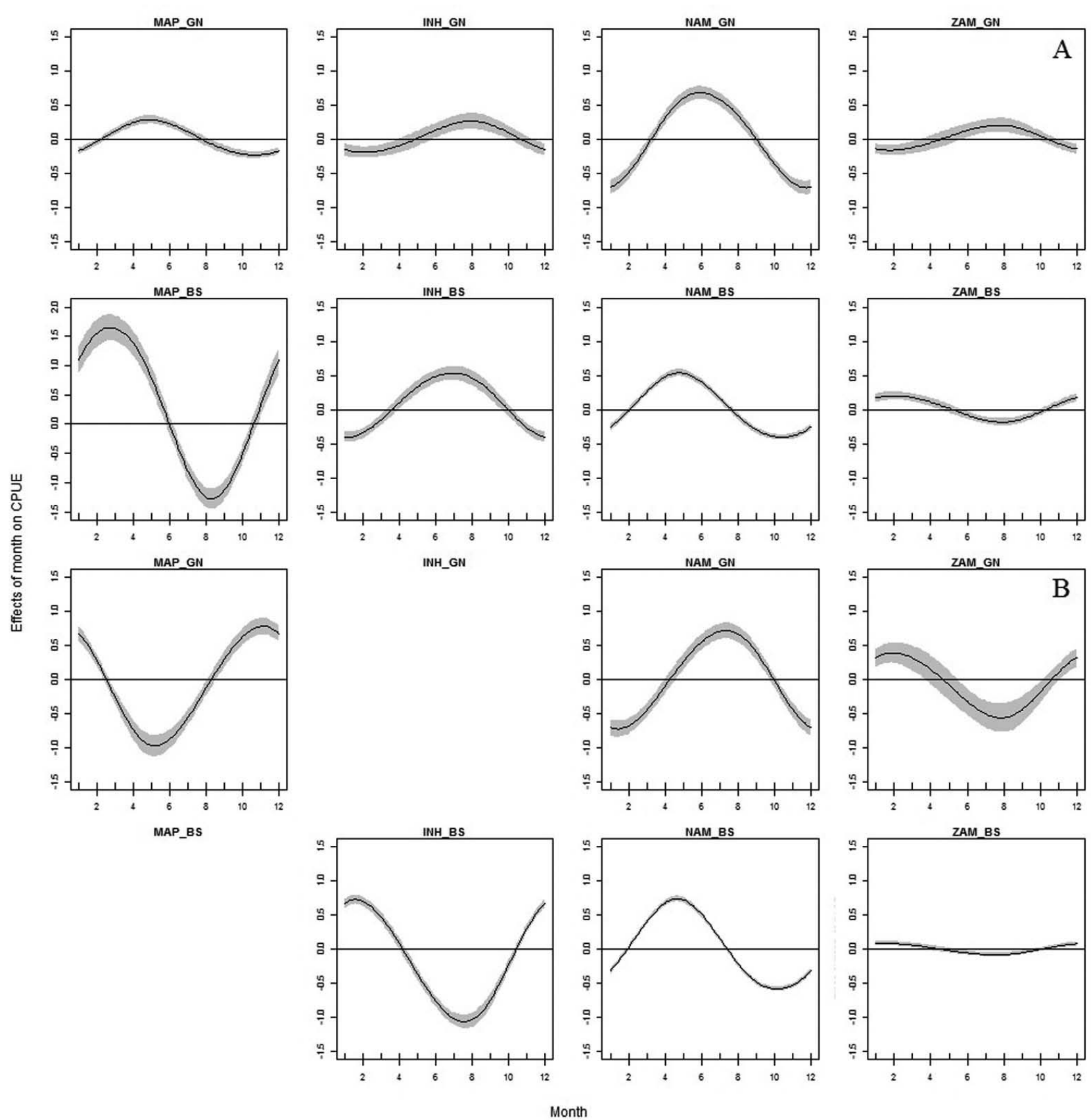

Fig. 4. - Shape of the month effect as estimated by the GAM model with the estimated $95 \%$ confidence intervals for each province and gear (see Table 3 for details); A, Hilsa kelee; B, Tryssa vitrirostris.

food, income and as a source of employment in the boat-building sector (Berkes et al. 2001, FAO 2004). In addition to the importance for the subsistence of a large portion of the coastal populations around the world (Onyango and Jentoft 2010), especially in Africa artisanal fisheries play a central role in alleviating household poverty (FAO 2005a,b). However, general knowledge about artisanal fisheries around the world is rather scarce and more information is urgently needed (e.g. Salas et al. 2007)

The analyses performed here are an attempt to quantify the changes for some of the species exploited by the artisanal fisheries along the Mozambican coast. The results show that the species analysed have de- clined in some of the provinces but have been stable or even increased in others. Nevertheless, both the combined CPUE of the target species, HKE and TVI, and the total CPUE of all the analysed species have significantly declined. However, it is important to note that for some of the models the deviance explained was rather low.

The monitoring programme of artisanal fisheries in Mozambique follows statistically sound on-shore catch sampling methods, as described in ICES (2013), with a spatio-temporal sampling frame based on site-days. The sampling frame, however, does not cover all landing sites along the coast, and this undercoverage may cause bias. Also, the multi-stage design, in which catch data 

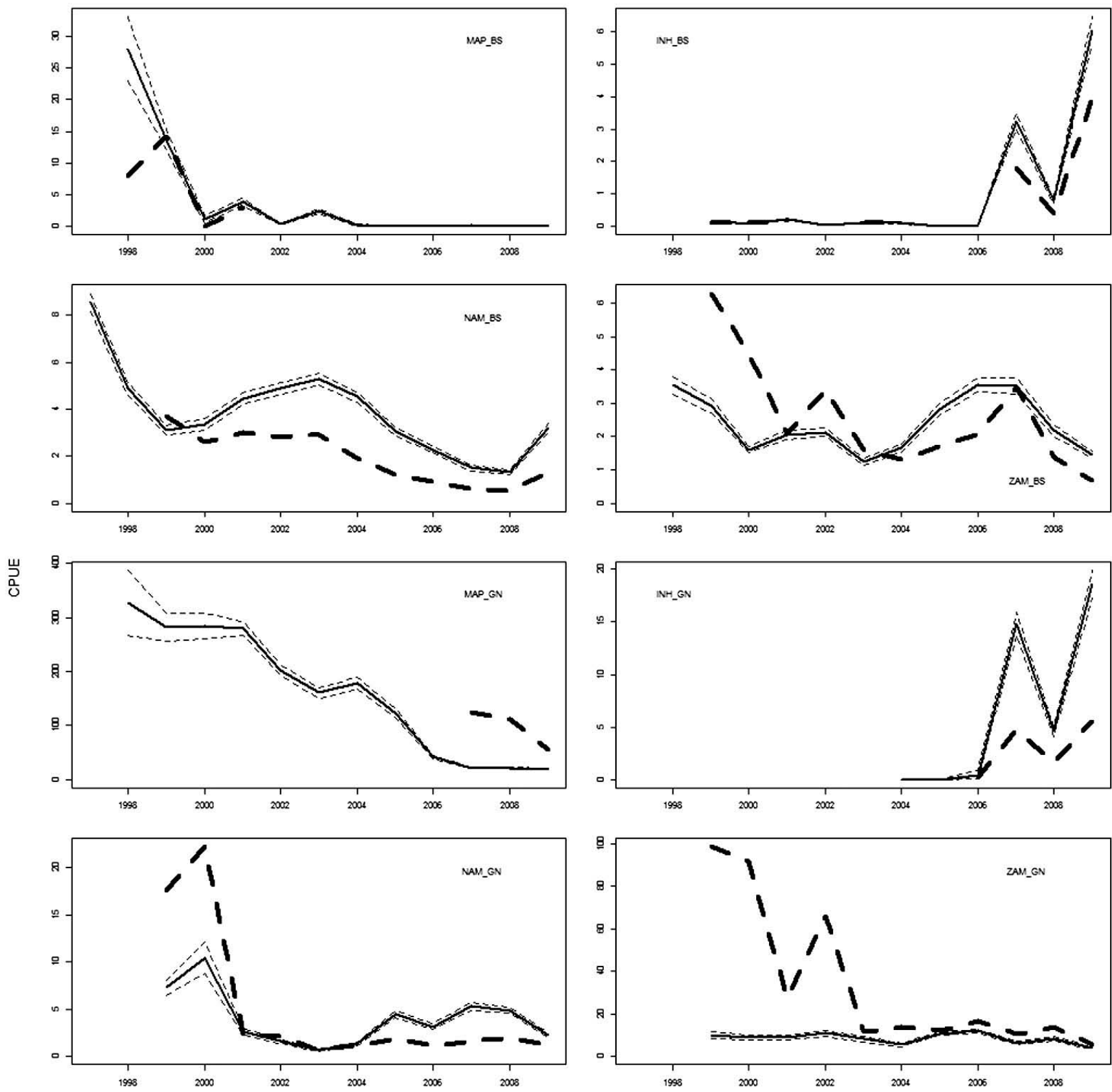

Year

Fig. 5. - Yearly average CPUE ( $\mathrm{kg} \mathrm{day}^{-1}$, continuous line) and CPUENET $\left[\mathrm{kg} \mathrm{day}^{-1}\right.$ (m of nets) ${ }^{-1}$, dashed line] of Hilsa kelee with the $95 \%$ confidence intervals as estimated by the GAMs for the provinces and gears analysed using final models (see Table 3 for details). CPUENET is multiplied per 100 for a straightforward representation, except for MAP_BS, which was multiplied per two. See Table 3 for model code and statistical details.

are chosen from trips that are selected within selected landing sites and days, results in a complex hierarchical structure of the data. For this analysis we ignored one level of clustering for simplicity, and assumed that trips were representatively sampled in time and space. This assumption is reasonably well supported since the sampling effort was approximately proportional to fishing effort. Because of the wide spatial and temporal distribution of effort and minimal changes in fishing technology over time, we believe that our estimates of CPUE may realistically reflect changes in fish biomass over time.

For some provinces our analyses showed a large decline in the CPUE of the two species during the first period of our time series (from 1998 to 2002), while the decline after 2002 was minor. This might be partially explained by the fact that the period from 1996 to 1998 was characterized by drought conditions (Kolding et al. 2003), creating poor living conditions for the people engaged in the agricultural sector and causing a shift in work force from farming to fishing, with a subsequent increase in fishing effort that might have triggered the observed decline through overfishing. The sharp decline in CPUE between 1998 and 2002 might, however, also result from the fact that the sampling design started to be implemented at the beginning of the time series, and thus early estimates could be biased due to incomplete coverage (although the estimated model uncertainty is similar along the times series). Despite the uncertainty in the estimates 

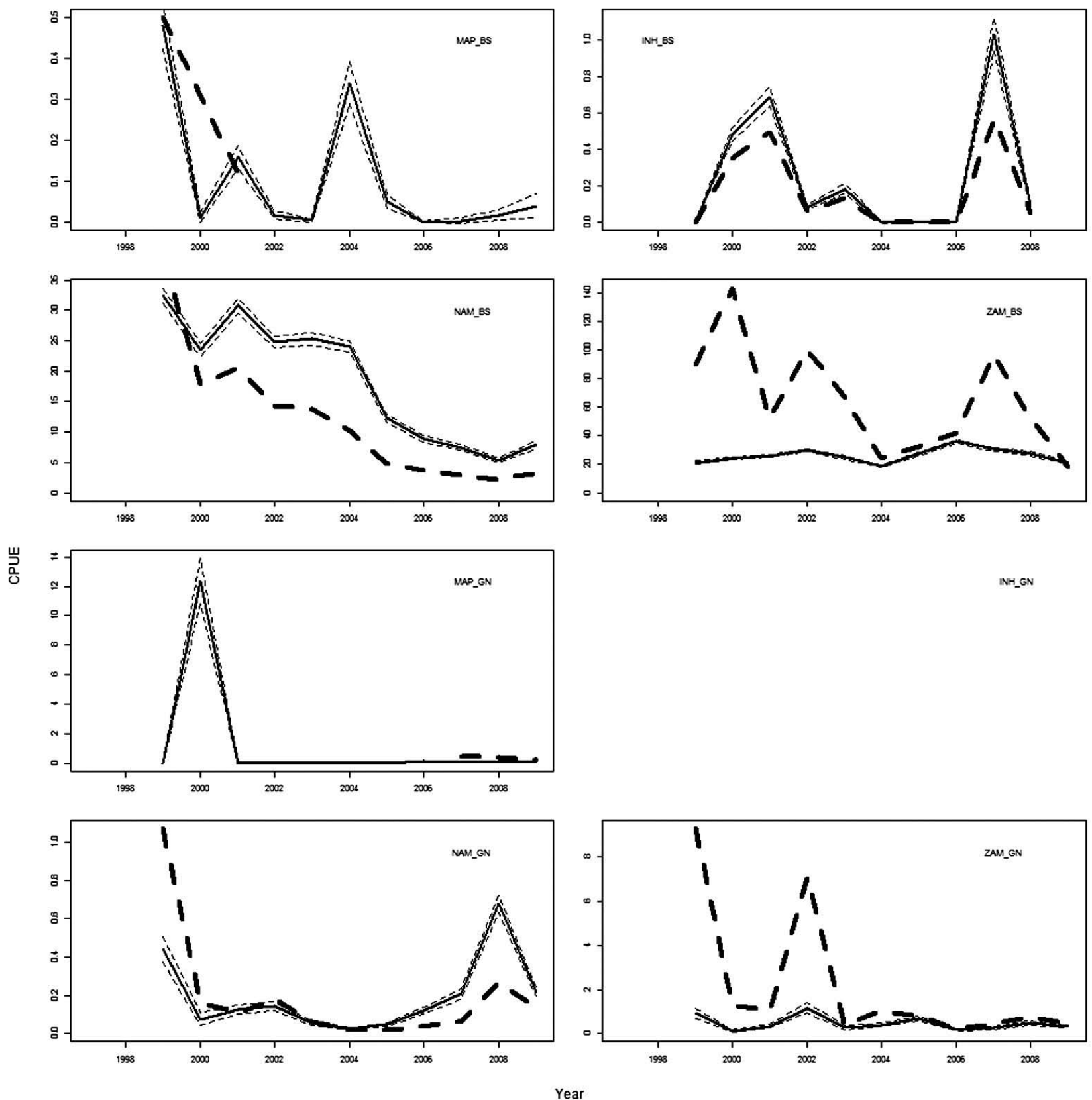

Year

Fig. 6. - Yearly average ( $\mathrm{kg} \mathrm{day}^{-1}$, continuous line) and CPUENET $\left[\mathrm{kg} \mathrm{day}^{-1} \text { ( } \mathrm{m} \text { of nets) }\right)^{-1}$, dashed line] of Tryssa vitrirostris with the $95 \%$ confidence intervals as estimated by the GAMs for the provinces and gears analysed using final models (see Table 3 for details). CPUENET is multiplied per 100 for a straightforward representation, except for MAP_BS, which was multiplied per two. See Table 3 for species code and statistical details.

in the first few years of the time series, it is also important to stress that the exploitation of the coastal species analysed here started at least two decades before the beginning of the collection of data used in our study (Loureiro 2001). For example, HKE supported a semiindustrial fishery in Maputo Bay from 1973 to 1990, and declined during the same period likely due to overexploitation (Loureiro 2001). Also for TVI, a decline in the standing stocks offshore and in the catches of this species by beach seines during 1973-1990 as a consequence of the HKE semi-industrial fishery was reported by Mualeque and Santos (2011). Thus, the decline of the CPUEs found in our study might have started long before 1997, and thus be more pronounced than is estimated in our analysis.
It is important to stress that for the analysed fish species there are no data on fishing mortality in relation to sustainable level of exploitation that can quantify the relative impact of the fisheries, other anthropogenic causes (pollution, coastal degradation, etc.) or climate. For example, massive floods in southern Mozambique from February to May 2000 caused extensive damage to coral reefs by sedimentation (Obura et al. 2002, Pereira and Gonalves 2004) and these events might have had a significant impacts on the stocks. Therefore, factors other than exploitation may also contribute to explain the observed trends, but the lack of data does not allow us to discriminate between the different causes.

The management of artisanal fisheries is crucial to allow them to continue supporting the local human com- 
munities who depend upon them (Davies et al. 2009). The knowledge of the status of the exploited stocks is the first step in the direction of sustainable exploitation and the analyses conducted here might provide managers with some of the basic instruments to initiate and promote the sustainable management of coastal marine resources in Mozambique. Our study also shows the importance of continuous monitoring of the artisanal fisheries in Mozambique. Assessment of the stock status based on data collected from the ongoing monitoring programme could be used as a set of indicators for deciding upon future management actions and it is therefore important for the programme to continue and be strengthened. Moreover, the use of indicators based on CPUE is a simple and cost-effective method to be used when data for implementing analytical assessment models are lacking (e.g. Cardinale 2009). Trend analyses based on CPUE triggered large reactions in the media and environmental stakeholders in Indonesia (Cardinale M., pers. comm.) and can therefore push managers to initiate management actions.

\section{REFERENCES}

Allison E., Ellis F. 2001. The livelihood approach and management of small scale fisheries. Mar. Pol. 25: 377-388. http://dx.doi.org/10.1016/S0308-597X(01)00023-9

Berkes F., Mahon R., McConney P., Pollnac R., Pomeroy R. 2001. Managing small-scale fisheries. IDRC, Toronto.

Cardinale M. 2011. Fishery reform: many stocks secure. Nature 476: 282. http://dx.doi.org/10.1038/476282a

Cardinale M., Nugroho D., Hernroth L. 2009. Reconstructing historical trend in abundance of small pelagic fish species in the Java Sea using standardized commercial trip based catch per unit of effort. Fish. Res. 99: 151-158. http://dx.doi.org/10.1016/j.fishres.2009.05.015

Cardinale M., Doerner H., Abella A., Andersen J., Casey J., Döring R., Kirkegaard E., Motova A., Anderson J., Simmonds E. et al. 2013. Rebuilding EU fish stocks and fisheries, a process under way? Mar. Pol. 39: 43-52. http://dx.doi.org/10.1016/j.marpol.2012.10.002

Cleveland W.S. 1993. Visualizing data. Hobart Press, Summit, NJ.

Davies T.E., Beanjara, N., and Tregenza, T., 2009. A socio-economic perspective on gear based management in an artisanal fisheries in south west Madagascar. Fisheries Management and Ecology, 16: 279-289. http://dx.doi.org/10.1111/j.1365-2400.2009.00665.x

FAO 2004. The state of the world fisheries and aquaculture 2004. Food and agriculture organization of the United Nations, Rome.

FAO 2005a. Increasing the contribution of small scale fisheries to poverty alleviation and food security. FAO Technical Guidelines for Responsible Fisheries. No. 10. FAO Rome, 79 pp.

FAO 2005b. Report of the FAO/WorldFish center workshop on interdisciplinary approaches to the assessment of small scale fisheries. FAO Fisheries Report, No 787. FAO Rome, 44 p.

Hardt M.J. 2009. Lessons from the past: the collapse of Jamaican coral reefs. Fish and Fisheries, 10: 143-158. http://dx.doi.org/10.1111/j.1467-2979.2008.00308.x

Hastie T., Tibshirani R. 1990. Generalized additive models. London, Chapman and Hall.

Hutchings J.A., Reynolds J.D. 2004. Marine fish population collapses: consequences for recovery and extinction risk. Bioscience 54: 297-309. http://dx.doi.org/ 10.1641/0006-3568(2004)054[0297:MFPCCF]2.0.CO;2

ICES 2010. Report of the Joint ICES-STECF Workshop on methods for merging metiers for fishery based sampling (WKMERGE). ICES CM 2010/ACOM:40, 94 pp.

ICES 2013. Report of the second Workshop on Practical Implementation of Statistical Sound Catch Sampling Programmes,
6-9 November 2012, ICES Copenhagen. ICES CM 2012/ ACOM:54, $71 \mathrm{pp}$.

IDPPE 2004. Censo Nacional da Pesca Artesanal, 2002 [2002 National census of the artisanal fishery]. Maputo, Mozambique, $44 \mathrm{pp}$.

IDPPE 2009. Recenseamento da Pesca Artesanal, 2007. Principais Resultados. Instituto National de Desenvolvimento da Pesca de Pequena Escala. Maputo, 83 pp.

IIP 2007. Relatório Anual 2007. Instituto Nacional de Investigação Pesqueira, $65 \mathrm{pp}$.

Kolding J., Ticheler H., Chanda, B. 2003. The Bangweulu Swamp Fisheries, in management, co-management or no-management? Major dilemmas in southern African freshwater fisheries. In: Jul-Larsen E., Kolding J., Overå R., Raakjær Nielsen J., van Zwieten P.A.M. (eds), FAO Fisheries Technical Paper 426/2. Rome, FAO.

Loureiro N. 2001. Pescaria da Magumba da Baía de Maputo. In Instituto Nacional de Investigação Pesqueira (eds). Boletim de divulgação No 34. Seminário sobre as Pescarias da Baía de Maputo, pp 34.

Minami M., Lennert-Cody C.E., Gao W., Roman-Verdesoto, M. 2007. Modelling shark by-catch: the zero-inflated negative regression model with smoothing. Fish. Res. 84: 210-221. http://dx.doi.org/10.1016/j.fishres.2006.10.019

Mualeque D., Santos, J. 2011. Biology, fisheries and distribution of Thryssa vitrirostris (Gilchrist \& Thompson 1908) and other Engraulidae along the coast of the Sofala Bank, western Indian Ocean. Afr. J. Mar. Sci. 33(1): 127-137. http://dx.doi.org/10.2989/1814232X.2011.575108

Munro J.L. 1983. A cost-effective data acquisition system for assessment and management of tropical multi-species, multigear fisheries. Fishbyte 1: 7-11.

Obura D., Suleiman M., Motta H., Schleyer, M. 2002. Status of coral reefs in Eastern Africa: Kenya, Tanzania, Mozambique And South Africa. In: Willinson, C. (ed.), Status of Coral Reefs of the World. Australian Institute of Marine Science.

Onyango P., Jentoft S. 2010. Assessing poverty in small scale fisheries in Lake Victoria, Tanzania. Fish and Fisheries, 11: 250-263. http://dx.doi.org/10.1111/j.1467-2979.2010.00378.x

Pauly D., Mines, A.N. 1982. Small-scale fisheries of San Miguel Bay, Philippines: biology and stock assessment. ICLARM Technical Report 7, $124 \mathrm{pp}$

Pereira M., Gonçalves P.M.B. 2004. Effects of the 2000 southern Mozambique floods on a marginal coral community: the case at Xai-Xai. Afr. J. Aquat. Sci. 29:113-116. http://dx.doi.org/10.2989/16085910409503800

Pomeroy R., Nguyen K.A.T., Thong H.X. 2009. Small-scale marine fisheries policy in Vietnam. Mar. Pol. 33: 419-428 http://dx.doi.org/10.1016/j.marpol.2008.10.001

Salas S., Chuenpagdee R., Seijo J.C., Charles A. 2007. Challenges in the assessment and management of small scale fisheries in Latin America and the Caribbean. Fish. Res. 87: 5-16. http://dx.doi.org/10.1016/j.fishres. 2007.06.015

Scientific, Technical and Economic Committee for Fisheries (STECF) - Report of the Assessment of Mediterranean Sea stocks - (STECF 13-09) part I, (eds Cardinale M. (Chairman) Osio C. \& Charef A.). 2013. Publications Office of the European Union, Luxembourg. http://stecf.jrc.ec.europa.eu/reports/medbs

Vincent A.C.J, Meeuwig J.J., Pajaro M.G., Perante N.C. 2007. Characterizing a small scale, data-poor, artisanal fisheries: Seahorses in the central Philippines. Fish. Res. 86: 207-215. http://dx.doi.org/10.1016/j.fishres.2007.06.006

Wood S.N. 2001. mgcv: GAMs and Generalized Ridge Regression for R. R News 1/2: 20-25.

Wood S.N. 2004. Stable and efficient multiple smoothing parameter estimation for generalized additive models. J. Amer. Statist. Assoc. 99: 673-686 http://dx.doi.org/10.1198/016214504000000980

Wood S.N. 2006. Generalized Additive Models: An Introduction with R. Chapman and Hall/CRC.

Xiao Y.S. 1998. Two simple approaches to use of production models in fish stock assessment. Fish. Res. 34: 77-86. http://dx.doi.org/10.1016/S0165-7836(97)00064-7 